\title{
PEMBERDAYAAN SANTRI DI PONDOK PESANTREN ATTARBIYATUSSAKILAH KOTA KENDARI
}

\author{
Empowering The Students at The Attarbiyatussakilah Islamic Boarding School \\ of Kendari
}

\author{
Abd. Kadir M. \\ Balai Penelitian dan Pengembangan Agama Makassar \\ Jl. A.P. Pettarani No. 72 Makassar \\ Email: amassoweang@yahoo.co.id
}

Naskah diterima tanggal 03 Maret 2015. Naskah direvisi tanggal 20 Mei 2015. Naskah disetujui tanggal 03 November 2015.

\begin{abstract}
Abstrak
Penelitian ini mendiskripsikan berbagai kegiatan keterampilan dalam pemberdayaan santri yang dilakukan oleh Pondok Pesantren Attarbiyatussakilah dan menggambarkan peluang dan tantangan prospek pengembangannya. Dengan metode kualitatif, temuan penelitian menunjukkan bahwa Pondok Pesantren Attarbiyatussakilah melaksanakan dan mengembangkan berbagai macam keterampilan melalui kegiatan kurikuler dan ekstra kurikuler dengan melibatkan pimpinan, pembina, dan santri pesantren serta masyarakat di sekitar pesantren. Jenis kegiatan pemberdayaan yang dilakukan dan dikembangkan oleh pesantren disesuaikan dengan kondisi lingkungan, sarana dan prasarana, dan kemampuan yang dimiliki pesantren. Kegiatan dan pengembangan pemberdayaan memiliki prospek yang sangat urgen dalam pembekalan keterampilan bagi santri, penunjang kehidupan santri dalam kehidupan di pesantren, dan merupakan potensi sumber dana dalam pengelolaan pesantren.
\end{abstract}

Kata kunci: pemberdayaan, pesantren, santri

\begin{abstract}
This study described various skill activities in empowering the students conducted by Attarbiyatussakilah Islamic Boarding School and explored the opportunities and challenges of their development prospect. With qualitative method, the research findings indicate that Attarbiyatussakilah Islamic Boarding School implemented and developed a wide variety of skills through curricular and extra-curricular activities involving the leaders, supervisors, and the students as well communities around the school. The kinds of activities were adapted to the environmental condition, infrastructure, and capabilities of Islamic Boarding School. These activities and empowerment development have very urgent prospect in debriefing the skills for the students, in supporting the lives of students at the school, and in becoming the potential source of income for the school management.
\end{abstract}

Keywords: empowerment, Islamic Boarding School, students

\section{PENDAHULUAN}

$\mathrm{P}$ esantren merupakan lembaga pendidikan keagamaan tertua di Indonesia. Lembaga ini hadir sejak masuknya Islam di Nusantara dalam bentuk sederhana dan sangat terbatas (Azra, 2005: 1). Sebelum sistem pendidikan modern diperkenalkan oleh Belanda, pesantren adalah satu-satunya sistem pendidikan yang ada di Indonesia. Bahkan sampai sekarang, pesantren di Indonesia masih memainkan perannya sebagai pusat pembelajaran, meski harus bersaing dengan lembaga-lembaga pendidikan umum lainnya (Turmudi, 2004: 37). Kehadiran awalnya ditujukan 
sebagai upaya penguatan pemahaman agama, wadah penyebaran Islam, dan benteng pertahanan umat dalam bidang akhlak. Namun dalam perkembangannya, pesantren tidak hanya mengkaji ilmu-ilmu agama, tetapi juga ilmu-ilmu umum dan sains.

Dalam perjalanannya yang panjang melalui beberapa masa di Indonesia, pesantren mengalami pertumbuhan dan perkembangan, baik dari segi jumlah, maupun ragam tipe dan coraknya, sehingga pesantren memegang peranan yang penting dalam berbagai aspek. Pondok pesantren dengan berbagai harapan dan predikat yang dilekatkan padanya, sesungguhnya berujung pada tiga fungsi utama yang senantiasa diemban (Suhartini, 2005: 233), yaitu: pertama, sebagai pusat pengkaderan pemikirpemikir agama (center of excellence). Kedua, sebagai lembaga yang mencetak sumber daya manusia (human resource). Ketiga, sebagai lembaga yang mempunyai kekuatan melakukan pemberdayaan pada masyarakat (agent of development). Pondok pesantren juga dipahami sebagai bagian yang terlibat dalam proses perubahan sosial (social change) di tengah perubahan yang terjadi (Faozan, 2006: 88-102).

Walaupun pesantren masih berada pada idealisme awal pendiriannya, yaitu sebagai lembaga yang bergerak dalam pendidikan dan penyiaran agama Islam, namun idealisme tersebut tidak lagi memadai pada masa sekarang, tetapi pesantren juga mempunyai kepedulian yang tinggi terhadap problematika yang dihadapi masyarakat disekitarnya. Pesantren bukan hanya tampil sebagai pusat pendidikan keagamaan yang melahirkan pemikir agama, tetapi juga berperan mencetak para pemimpin masyarakat baik di bidang keagamaan, sosial maupun politik (Raharjo, 1985: 291). Upayaupaya yang dilakukan pesantren ini perlu mendapat perhatian yang lebih serius, sehingga pesantren tidak hanya sebagai lembaga tafaqquh $f i$ al-din (pusat pendalaman ajaran agama), tapi juga sebagai agen pemberdayaan masyarakat.

Pesantren berperan sebagai lembaga sosial kemasyarakatan yang dapat membantu pemerintah dalam menyebarluaskan inovasi pembangunan kepada masyarakat, dan sebagai wadah pemberdayaan masyarakat. Dengan peran tersebut, pesantren mampu berkembang dan menempatkan diri pada posisi yang penting dalam sistem pendidikan nasional Indonesia secara keseluruhan (Madjid, 1998: xxiv). Kini posisi pesantren semakin jelas melalui Undang-Undang Nomor 20 Tahun 2003 tentang Sistem Pendidikan Nasional, sehingga perannya sebagai penyelenggara pendidikan sangat penting dalam rangka proses pembudayaan dan permberdayaan peserta didikyang berlangsung sepanjang hayat.

Dalam rencana strategis (renstra) Pendidikan Islam 2010-2014, bahwa pendidikan pesantren memilikimisi (1) Membangun tradisi keilmuan pesantren yang berbasis pada literatur-literatur klasik (kutub al-turats) dan literatur-literatur kontemporer (kutub al-ashriyyah) melalui kegiatan pengajian (baths al-kutub) dan kajian (baths almasail); (2) Mengembangkan potensi berfikir dan berkarya serta merespon perkembangan iptek; (3) Menyelenggarakan pendidikan berwatak kewirausahaan (entrepreneurship) dengan berbagai keterampilan (life skill) sesuai dengan perkembangan masyarakat.

Pemerintah melalui Kementerian Agama dan kementerian terkait telah memberikan bantuan pada pesantren dalam berbagai bentuk dalam rangka penguatan sarana dan prasarana, penguatan kompetensi sumberdaya manusia, dan pengembangan potensi pesantren. Bahkan Kementerian Agama melakukan terobosan dengan mengembangkan pesantren vokasional untuk kegiatan pemberdayaan.

Walaupun telah dilakukan berbagai intervensi pemberdayaan di kalangan pesantren oleh pemerintah dalam hal ini Kementerian Agama, namun belum mendapatkan gambaran yang jelas mengenai dampak yang dihasilkan aksi pemberdayaan yang dimaksud. Guna memenuhi kebutuhan itulah penelitian ini sangat penting dilakukan dalam rangka memperoleh gambaran tentang peran pesantren dalam pemberdayaan santri.

Masalah pokok yang dirumuskan dalam penelitian ini adalah bagaimana pemberdayaan santri yang dilakukan oleh pondok pesantren? Masalah pokok tersebut dapat dirumuskan ke dalam tiga pertanyaan penelitian, yaitu: Bagaimana bentuk/macam pemberdayaan yang dilakukan di pesantren? Apa yang menjadi kendala dalam kegiatan pemberdayaan? dan Bagaimana hasil yang dicapai dalam kegiatan pemberdayaan? 
Tujuan penelitian ini bertujuan untuk mengidentifikasi kegiatan pemberdayaan santri yang dilaksanakan di Pesantren Attarbiyatussakilah, mencermati kegiatan pemberdayaan terhadap santri oleh pesantren, baik dari konsep, teknis, sampai pada hasil, sehingga diperoleh gambaran tentang substansi pemberdayaan yang dilakukan, memperoleh gambaran dinamikan pesantren dalam kegiatan pemberdayaan untuk menemukan langkah selektif terhadap problem pemberdayaan dan pengembangan terhadap prospeknya.

Hasil penelitian diharapkan dapat berguna bagi instansi-instansi pemerintahan, terutama di jajaran Kementerian Agama dan Pemerintah Daerah setempat sebagai informasi dan masukan dalam rangka diversifikasi pembinaan penguatan pemberdayaan di pondok pesantren dengan pertimbangan dukungan potensi dan prospek kewilayahan, sehingga santri dan alumni dapat berperan nyata di dalam masyarakat. Selain itu penelitian ini dapat bermanfaat bagi pembina dan pengelola pesantren untuk melakukan optimalisasi pengelolaan dan perluasan jangkauan pengembangannya, sehingga pesantren tidak hanya tempat meminta berkah, tetapi tempat memberi berkah dan mengembangkan peluang.

Demikian pula hasil penelitian itu dapat mendorong pelaku dunia usaha untuk membangun kemitraan, mulai dari perencanaan, proses sampai kepada produksi dan pemasaran untuk menumbuhkembangkan kewirausahaan berbasis pesantren.

\section{Tinjauan Pustaka}

\section{Konsep Pemberdayaan}

Pemberdayaan diartikan juga dengan penguatan. Menurut Suharto (2005: 58) pemberdayaan adalah proses sebagaimana orang menjadi cukup kuat untuk berpartisipasi dalam berbagai pengontrol atas dan mempengaruhi terhadap kejadian-kejadian serta lembaga-lembaga yang mempengaruhi kehidupannya. Pemberdayaan menekankan bahwa orang memperoleh keterampilan, pengetahuan, dan kekuasaan yang cukup untuk mempengaruhi kehidupannya dan kehidupan orang lain.

Pemberdayaan adalah program pengembangan yang dilakukan oleh pesantren, baik sebagai penguatan pesantren secara kelembagaan maupun terhadap santri. Kegiatan pemberdayaan yang dilakukan di pesantren adalah pelibatan santri, baik sebagai subjek maupun sebagai objek. Program pengembangan itu berupa pemberian keterampilan, usaha ekonomi, budidaya, dan jasa.

Secara implisit, pemberdayaan santri dinyatakan dalam Peraturan Menteri Agama No. 13 tahun 2014 Bab II, apasl 7 ayat 1 bahwa santri adalah peserta didik dan wajib bermukim di pondok atau asrama pesantren. Kewajiban bermukim di pondok atau asrama pesantren dimaksudkan untuk lebih mengintensifkan proses pendidikan.

Tujuan yang ingin dicapai dari pemberdayaan jika dikaitkan dengan pemberdayaan santri adalah untuk membentuk individu santri pesantren menjadi mandiri. Kemandirian tersebut meliputi kemandirian berfikir, bertindak, dan mengendalikan apa yang mereka lakukan tersebut yang memberikan manfaat, baik pesantren secara internal maupun secara eksternal masyarakat di lingkungan pesantren.

\section{Karakteristik Pesantren}

Secara terminologi, pesantren didefinisikan sebagai lembaga pendidikan tradisional Islam untuk mempelajari, memahami, mendalami, menghayati, dan mengamalkan ajaran Islam dengan menekankan pentingnya moral keagamaan sebagai pedoman prilaku sehri-hari (Mastuhu, 1994: 55).

Sebagai lembaga pendidikan Islam tertua di Indonesia, pesantren mengalami perkembangan sesuai dengan perkembangan zaman terutama adanya kemajuan ilmu pengetahuan dan teknologi. Perubahan bentuk pesantren bukan berarti pesantren kehilangan ciri khasnya. Sistem pesantren adalah sarana yang berupa perangkat organisasi yang diciptakan untuk mencapai tujuan pendidikan yang berlangsung dalam pesantren (Arifin, 1995: 257).

Dalam perkembangannya, pesantren muncul dalam berbagai tipe dan pola berdasarkan bangunan fisik, kurikulum, dan berdasarkan output yang dihasilkan. Berdasarkan bangunan fisik dan sarana pendidikan yang dimiliki, pesantren mempunyai lima pola, yaitu: pola pertama: Masjid dan rumah kyai; pola kedua: masjid, rumah kyai dan pondok; pola ketiga: masjid, rumah kyai, pondok, dan madrasah; pola keempat: masjid, rumah kyai, pondok, madrasah, dan tempat ketrampilan; pola 
kelima: masjid, rumah kyai, pondok, madrasah, tempat keterampilan, universitas, gedung pertemuan, tempat olahraga, sekolah umum (Daulay, 2007: 66).

Berdasarkan kurikulum atau sistem pendidikan yang dipakai, pesantren mempunyai tiga tipe, yaitu pesantren tradisional, modern, dan pesantren komprehensif. Pesantren tradisional (salafi) yaitu pesantren yang memberikan pengajaran dengan sumber kitab-kitab klasik Islam atau kitab kuning dalam bentuk sistem sorogan, pengetahuan non agama tidak diajarkan, dan kurikulum sepenuhnya ditentukan oleh para kyai pengasuh pondok (Mastuhu, 1994: 157). Pesantren Modern (khalafi) adalah pesantren yang menerapkan sistem madrasah dalam bentuk klasikal dan memasukkan pengetahuan umum dan keterampilan dalam kurikulum. Pesantren komprehensif adalah sistem pendidikan dan pengajaran gabungan antara tradisional dan modern (Ghazali, 2001: 14-15). Pendidikan diterapkan dengan pengajaran kitab kuning dengan metode sorongan, bandongan dan wetonan yang biasanya diajarkan pada malam hari sesudah salat Magrib dan sesudah salat Subuh. Proses pembelajaran sistem klasikal dilaksanakan pada pagi sampai siang hari seperti di madrasah/ sekolah pada umumnya.

Dilihat dari output yang dihasilkan, pesantren dapat dibagi dalam empat tipe, yaitu pesantren tipe A, yaitu pesantren yang mempunyai target output santri yang berkepribadian soleh dan mampu menguasai kitab-kitab klasik dan mampu membaca kitab kuning sendiri serta mempunyai keahlian khusus tertentu. Pesantren tipe B adalah pesantren yang mempunyai target output santri yang berkepribadian soleh dan mampu menguasai kitab-kitab klasik dan mampu membaca kitab kuning sendiri. Pesantren tipe $\mathrm{C}$, yaitu pesantren yang mempunyai target output santri yang berkepribadian soleh dan mempunyai keahlian praktis lain atau ketrampilan khusus misalnya trampil bahasa asing, trampil di bidang pertaniaan, peternakan dan sebagainya. Pesantren tipe $\mathrm{D}$, yaitu pesantren yang hanya menghasilkan output santri yang berkepribadian soleh dan memahami ajaranajaran dasar agama. Santri pesantren model ini belum tentu berkemampuan bisa membaca kitab kuning secara sendiri ketika keluar dari pesantren (Murtadho, 2014).
Tipe dan pola pesantren tersebut memberikan gambaran bahwa pesantren merupakan lembaga pendidikan Islam yang berjalan dan berkembang sesuai dengan tuntutan zaman. Dimensi kegiatan sistem pendidikan dilaksanakan oleh pesantren bermuara pada sasaran utama yaitu perubahan baik secara individual maupun kolektif. Perubahan itu berwujud pada peningkatan persepsi terhadap agama, ilmu pengetahuan dan teknologi. Santri juga dibekali dengan pengalaman dan keterampilan dalam rangka meningkatkan sumber daya manusia.

\section{METODE PENELITIAN}

Untuk mengetahui gambaran pemberdayaan santri, lokasi dan sasaran penelitian ditentukan secara sengaja (purposive), yaitu Pondok Pesantren Attarbiyatussakilah di Kota Kendari. Penentuan lokasi dan sasaran penelitian ini didasarkan pada studi awal dengan pertimbangan bahwa Pondok Pesantren Attarbiyatussakilah yang terletak di Kota Kendari merupakan salah satu pesantren yang sejak berdirinya telah melaksanakan pemberdayaan santri dalam berbagai keterampilan.

Untuk memenuhi data yang diperlukan dalam penelitian ini, ditempuh tiga teknik pengumpulan data, yaitu studi pustaka, wawancara, dan observasi. Studi pustaka dilakukan dengan menelusuri dan mengumpulkan informasi tentang permasalahan penelitian. Wawancara, dilakukan dalam dua bentuk; Pertama, secara terstruktur yaitu dengan memakai format tertulis yang telah disediakan berupa uraian-uraian pertanyaan berkaitan dengan pokok-pokok permasalahan penelitian. Selanjutnya diperhadapkan secara langsung kepada pihak informan. Kedua, wawancara tidak terstruktur yang dilakukan tanpa format tertulis, melainkan bersifat kondisional sesuai kebutuhan data. Observasi dalam penelitian ini dilakukan di lokasi pesantren sasaran penelitian untuk melihat secara langsung kondisi pesantren dan kegiatan pemberdayaan santri yang dilakukannya.

Dengan menggunakan pendekatan kualitatif, analisis yang digunakan dalam penelitian ini berpegang pada perinsip penelitian kualitatif, yaitu pengumpulan, pengolahan dan analisis data dilakukan secara bersamaan selama proses penelitian. Proses analisis data berpedoman pada pandangan Milles dan Huberman (1992) bahwa analisis kualitatif tetap menggunakan kata-kata 
yang biasanya disusun dalam teks yang diperluas. Analisis dimulai dengan menelaah data yang tersedia dalam berbagai sumber, yaitu wawancara, pengamatan dan penelusuran pustaka dan dokumen. Penelaahan data dilakukan dengan cara membaca dan mempelajari secara seksama untuk menentukan relevansi antara data yang diperoleh dengan permasalahan yang diteliti. Keseluruhan data dikelompokkan kemudian diinterpretasi dan disusun dalam bentuk pernyataan-pernyataan.

\section{PEMBAHASAN}

\section{Sekilas Kota Kendari}

Kendari merupakan ibu kota propinsi Sulawesi Tenggara dan salah satu dari dua belas daerah tingkat dua yang ada dalam wilayah Provinsi Sulawesi Tenggara. Kedua belas daerah tingkat dua itu terdiri atas dua daerah yang berstatus kota, yaitu Kota Kendari dan Kota Bau-Bau, sedangkan sepuluh daerah yang berstatus kabupaten, yaitu Kabupaten Bombana, Buton, Buton Utara, Kolaka, Kolaka Utara, Konawe, Konawe Selatan, Konawe Utara, Muna, dan Kabupaten Wakatobi (BPS, 2013:2).

Secara historis, wilayah Kota Kendari pada yang lalu termasuk dalam wilayah Kerajaan Konawe yang pernah berdiri dan mengalami puncakpuncak kejayaannya sekitar abad XV-XIX (Hafid dan Misran, 2007: 27). Kerajaan Konawe akhirnya runtuh setelah mengalami perpecahan ke dalam lalu digantikan dengan Kerajaan Laiwoi yang di bantu oleh pemerintah Hindia Belanda akhir abad XIX melalui perjanjian " Lang Tractat “ (1858).

Kota Kendari terletak di jazirah tenggara Pulau Sulawesi. Sebagian besar wilayahnya terdapat di daratan mengelilingi Teluk Kendari dan terdapat satu pulau, yaitu Pulau Bungkutoko. Secara geografis, wilayah Kota Kendari berbatasan dengan Kecamatan Soropia, Kabupaten Konawe di sebelah utara, Laut Kendari di sebelah timur, Kecamatan Moramo dan Kecamatan Konda, Kabupaten Konawe Selatan di sebelah selatan, dan di sebelah barat berbatasan dengan Kecamatan Ranomeeto dan Kecamatan Sampara Kabupaten Konawe Selatan.Wilayah administrasi pemerintahan Kota Kendari terdiri atas sepuluh kecamatan, yaitu Kecamatan Mandonga, Kendari, Poasia, Baruga, Abeli, Kendari Barat, Puuwatu, Wua-Wua, Kadia, dan Kecamatan Kambu.

Menurut data BPS tahun 2013, jumlah penduduk Kota Kendari sebanyak 304.862 orang, terdiri atas laki-laki 153.922 orang dan perempuan 150.940 orang. Penduduk tersebut tersebar dengan persebaran yang tidak merata, dan dengan luas wilayah $14.499 .07 \mathrm{~km}$ persegi berarti kepadatan penduduknya mencapai 158.40 jiwa/kilometer persegi. Secara keseluruhan jumlah penduduk yang berjenis kelamin laki-laki lebih banyak dari jumlah penduduk yang berjenis kelamin perempuan, yang tercermin dari angka rasio jenis kelamin yang lebih besar dari 100, yaitu 104.43. Penduduk tersebut tersebar ke dalam sepuluh kecamatan dengan jumlah yang cukup bervariasi. Bagian terbesar penduduk berada pada Kecamatan Kendari Barat dengan jumlah penduduk 45.132 orang, dan kecamatan yang paling sedikit penduduknya adalah Kecamatan Baruga dengan jumlah penduduk 20.363 orang.

Dilihat dari segi agamanya, masyarakat Kota Kendari heterogen, terdiri atas Islam sebanyak 267.264 orang (94.19\%), Kristen 9.694 orang (3.42\%), Katolik 5.170 orang (1.82\%), Hindu 1.155 orang $(0.41 \%)$, dan Budha 471 orang $(0.17 \%)$. Data tersebut menunjukkan bahwa penduduk Kendari mayoritas beragama Islam. Penduduk yang memeluk agama Islam pada umumnya terdiri dari orang-orang Tolaki yang merupakan penduduk asli daerah ini.

Masuknya agama Islam di daerah ini pada masa Kerajaan Konawe akhir abad ke-16 yaitu kurang lebih 16 tahun setelah Kesultanan Buton menerima Islam. Islam masuk di Kerajaan Konawe secara tidak resmi pada masa pemerintahan Tebawo (Sangia Inato) khususnya di daerah-daerah pesisir pantai yang langsung berhubungan dengan pedagang-pedagang dari luar (Alhadza (a), 2009: 55). Penyebaran Islam dilakukan oleh mubalig utusan Raja Waimuddin yang melakukan dakwah di wilayah Kerajaan Huton dan sekitarnya (Supriyanto dkk, 2009: 191).

Pada masa pemerintahan Mokole Lakidende (Raja Lakidende II) sekitar abad ke-18 agama Islam diterima sebagai agama kerajaan, sehingga Raja Mokole mendapat gelar Sangia Ngginoburu, karena ia sebagai raja Konawe pertama yang memeluk Islam (Alhadza (b), 2009: 62). Pusat-pusat penyiaran Islam di Kerajaan Konawe dimulai di pesisir pantai antara lain pantai Tinanggea, Kolono, Torobulu, Ngapaaha, Lasolo, dan Muara Sampara. Setelah itu barulah Islam masuk di daerah-daerah pedalaman termasuk di pusat Kerajaan Konawe di Unaaha (Melamba dkk, 2013: 269). 


\section{Gambaran Pendidikan Islam}

Sebagai ibukota Propinsi Sulawesi Tenggara, Kendari memiliki sarana pendidikan yang cukup untuk memenuhi kebutuhan masyarakat mulai dari tingkat taman kanak-kanak sampai perguruan tinggi, baik yang dikelola oleh pemerintah maupun swasta. Taman kanak-kanak sebanyak 87 buah dengan jumlah murid 4.891 orang dan guru 645 orang, SD. Negeri/Swasta sebanyak 139 buah dengan jumlah murid 38.243 orang dan guru 2.424 orang, SLTP Negeri/Swasta sebanyak 50 buah dengan jumlah siswa 16.684 orang dan guru 1.547 orang, SLTA Negeri/Swasta sebanyak 50 buah dengan jumlah siswa 17.296 orang dan guru 1.830 orang, dan Perguruan Tinggi Negeri/Sawasta sebanyak 9 buah dengan jumlah mahasiswa 25.940 orang dan dosen 1.966 orang (BPS, 2013: 97-105).

Lembaga pendidikan agama Islam tumbuh dan berkembang beriringan dengan lembaga lembaga pendidikan umum sesuai dengan laju pertumbuhan dan perkembangan penduduk. Sebelum adanya lembaga pendidikan formal, pendidikan agama hanya diberikan dalam bentuk tradisional, yaitu pendidikan agama mlalui rumah tangga dan mesjid. Pendidikan agama yang diberikan hanya terbatas pada mengenal dan dapat membaca Kitab Suci Alquran beserta pengetahuan agama Islam.

Sampai saat ini, lembaga pendidikan agama Islam di Kota Kendari tersedia mulai dari tingkat dasar sampai tingkat perguruan tinggi, baik yang dikelola oleh pemerintah maupun swasta. Sesuai data yang didapatkan dari Kantor Wilayah Kementerian Agama Provinsi Sulawesi Tenggara, madrasah yang telah didirikan oleh pemerintah terdiri atas 1 Madrasah Ibtidaiyah Negeri (MIN ), 1 buah Madarasah Tsanawiyah Negeri (MTsN), 1 buah Madrasah Aliyah Negeri (MAN), dan 1 buah perguruan tinggi yaitu Sekolah Tinggi Agama Islam Negeri (STAIN) Sultan Qaimuddin Kendari. Selain itu, lembaga pendidikan Islam yang didirikan oleh masyarakat Islam, terdiri atas 20 buah Raudhatul Atfal (RA), 10 buah Madrasah Ibtidaiyah Swasta (MIS), 12 buah Madrasah Tsanawiyah Swasta (MTs), dan 6 buah Madrasah Aliyah Swasta (MAS).

Data tersebut menunjukkan bahwa umat Islam Kota Kendari memiliki perhatian yang besar terhadap pendidikan Islam, dengan mendirikan madrasah-madrasah, mulai dari Raudhatul Athfal sampai perguruan tinggi. Selain itu, umat Islam telah mampu mendirikan sembilan pondok pesantren, yaitu Pesantren Ummushshabri, Annur, Alqadiriyyah, Al-Fath, Minhajussunnah, Hidayatullah, Al-Mu'minin, dan Pesantren Shohibul Qur'an.

\section{Profil Pesantren Attarbiyatussakilah Sejarah Berdirinya}

Pondok Pesantren Attarbiyatussakilah terletak di Jalan Banteng, Kelurahan Anduonohu, Kecamatan Poasia, Kota Kendari, sekitar satu kilometer di sebelah timur Kantor Gubernur Provinsi Sulawesi Tenggara. Pesantren ini didirikan pada tahun 2004 di bawah naungan Yayasan Pendidikan/Lembaga Bina Muallaf dan Kaum Dhuafa Provinsi Sulawesi Tenggara, berdasarkan Akta Notaris Hidayat, SH. Nomor 74 Tahun 2002 (Supriyanto dkk, 2013: 261).

Sebelum pondok pesantren ini berdiri, Yayasan Pendidikan/Lembaga Bina Muallaf dan Kaum Dhuafa pada awalnya melakukan kegiatan pembinaan para muallaf di Kota Kendari melalui suatu lembaga yang disebut "Lembaga Bina Muallaf-Kaum Dhuafa (LBM-KD) yang diprakarsai dan dipimpin oleh Drs. Muchtar Badawi (Badawi, Wawancara 19 September 2014). Hal itu dilakukan karena sebagian besar para muallaf itu setelah memeluk Islam tidak mendapatkan pembinaan yang dilakukan secara kontinu oleh suatu lembaga khusus, sehingga mereka bingung, kurang memahami ajaran Islam dengan benar dan tidak melaksanakan ibadah dengan baik.

Pembinaan para muallaf dilakukan lembaga ini pada lima mesjid yang tersebar di Kota Kendari, yaitu Mesjid Raya Kelurahan Kessilampe, Mesjid Nurul Iman Sodooha, Mesjid Agung Alkausar Kendari, Mesjid Riyadul Jihad Pasar Anduonohu, dan Mesjid Raya Puday Kecamatan Abeli Kota Kendari. Pembinaan dilakukan dalam bentuk pengajian setiap minggu dengan materi yang berkaitan dengan ajaran Islam, yaitu pembinaan aqidah Islam, ibadah, muamalah, akhlak, praktek shalat, menghafal bacaan shalat, pengajaran baca tulis Alquran, serta menghafal surah-surah pendek dalam Alquran (Badawi, Wawancara 20 September 2014).

Selain kegiatan pembinaan muallaf, Yayasan Pendidikan/Lembaga Bina Muallaf dan Kaum Dhuafa melaksanakan kegiatan dan usaha di berbagai bidang sebagaimana yang tercantum dalam 
Anggaran Dasar Yayasan, yaitu kegiatan di bidang pendidikan formal dan non formal, sosial ekonomi, dan pembinaan keterampilan.

Usaha dan kegiatan yayasan dibidang pendidikan didorong oleh keprihatinan terhadap keadaan pendidikan anak-anak, dengan banyaknya anak-anak yang tidak mendapatkan kesempatan mengenyam pendidikan. Rendahnya kesempatan bagi masyarakat untuk mengenyam pendidikan disebabkan oleh berbagai hal, antara lain karena tingkat kehidupan masyarakat berada pada kelas menengah ke bawah, sehingga banyak orang tua merasa tidak mampu menyekolahkan anakanaknya.

Keinginan Muchtar Badawi sebagai ketua Yayasan untuk mendirikan lembaga pendidikan keagamaan berupa pondok pesantren mendapat sambutan dari Asri Imran Tanda, salah sorang tokoh masyarakat di Kelurahan Anduonohu untuk menyerahkan sebagian tanahnya seluas 16 hektar kepada pesantren, terdiri atas satu hektar diwakafkan untuk lokasi pembangunan kampus pesantren dan 15 hektar diserahkan sebagai hak pakai selama jangka waktu 25 tahun untuk kegiatan agrobisnis dan agroindustri dalam rangka menunjang dan mempercepat pembangunan kampus pondok pesantren (Badawi, Wawancara 20 September 2014).

Pada awal berdirinya pondok pesantren ini diberi nama dengan Pondok Pesantren Assakinah yang berarti 'keluarga yang bahagia", kemudian nama tersebut dirubah menjadi "Attarbiayatussakilah" yang berarti 'pendidikan keterampilan" atas usul pejabat Bagian Kesra Kantor Gubernur Provinsi Sulawesi Tenggara, dan nama itulah yang digunakan sampai sekarang.

\section{Kegiatan Pendidikan}

Sebagai lembaga pendidikan keagamaan, Pesantren Attarbiyatussakilah memiliki visi, yaitu unggul dalam iptek, istiqamah dalam imtaq, dan akhlakul karimah. Misinya adalah melaksanakan teori dan praktek kegiatan belajar mengajar. Sedangkan tujuan yang ingin dicapai adalah membentuk generasi muslim yang teologis, simpatik, dan kharismatik yang berkepribadian islami, disiplin, tangguh, mandiri, cerdas, terampil, sehat rohani dan jasmani, serta bertanggung jawab.

Untuk mencapai tujuan tersebut, Pondok Pesantren Attarbiyatussakilah melaksanakan kegiatan pendidikan yang terbagi atas dua macam, yaitu Pendidikan Formal dan Pendidikan Kepesantrenan. Pendidikan formal terdiri atas tiga jenjang, dua jenjang pendidikan di bawah koordinasi Kementerian Agama dan menggunakan kurikulum Kementerian Agama, yaitu Madarasah Ibtidaiyah yang diberi nama dengan Madrasah Ibtidaiyah Insan Cendekia Islamiyah, dan Madrasah Tsanawiyah yang diberi nama dengan Madrasah Tsanawiyah Peskil. Satu jenjang pendidikan di bawah koordinasi Kementerian Pendidikan Nasional dan menggunakan kurikulum Kementerian Pendidikan Nasional, yaitu Sekolah Menengah Kejuruan yang diberi nama dengan Sekolah Menengah Kejuruan Life Skill.

Proses belajar mengajar di lembaga pendidikan formal dilaksanakan pada pagi hari mulai jam 07.15 sampai jam 13.30 siang. Sedangkan pendidikan kepesantrenan dilaksanakan sesudah salat Subuh dan sesudah salat Magrib dengan menggunakan kurikulum kepesantrenan dan terdiri atas beberapa materi pelajaran, yaitu Ilmu Dasar Alquran/Iqra', Belajar Teori dan Praktek Tajwid, Balajar Tafsir Alquran dan Alhadis, Latihan Dakwah dan Latihan Pedato serta MC, dan Tahfizul Quran dan Sunnah (Badawi, Wawancara 20 September 2014).

Latihan dakwah, pedato dan MC dilaksanakan setiap hari setelah shalat Dhuhur berjamaah di mesjid dan mushallah dalam pesantren. Setiap hari ditunjuk secara bergiliran dua orang sanri, satu yang ditunjuk sebagai MC (protokol) dan satu ditunjuk sebagai pemceramah. Santri yang dianggap sudah mampu sebagai MC dan penceramah ditunjuk dua orang secara bergiliran pada upacara apel pagi setiap hari Sabtu yang dilaksanakan di lapangan yang dihadiri oleh seluruh siswa, guru dan pembina, satu orang sebagai protokol dan satu orang sebagai penceramah (Harfin, Wawancara, 20 September 20140.

\section{Keadaan Santri, Kiyai, dan Guru/Pembina}

Jumlah santri yang belajar di pondok pesantren ini sebanyak 271 orang, terdiri atas 146 orang laki-laki dan 125 orang perempuan. Semua santri tersebar pada tiga jenjang pendidikan formal dalam pesantren, terdiri atas 71 orang yang belajar pada Madrasah Ibtidaiyah, 106 orang belajar pada Madrasah Tsanawiyah, dan 94 orang belajar pada Sekolah Menengah Kejuruan. Sebagian besar santri 
pesantren masuk dalam katagori miskin dengan jumlah 235 orang. Mereka masuk dan belajar di pesantren secara gratis, yaitu gratis tinggal di asrama, gratis biaya hidup, makan tiga kali sehari, ditanggung pakaian sekolah, buku, dan alat tulis. Sedangkan santri yang mampu dibebani uang masuk dan biaya hidup yang dibayar setiap bulan.

Jumlah santri pesantren yang terdaftar sebagai anak Panti Asuhan Amaliah sebanyak 103 orang, terdiri atas 57 orang laki-laki dan 46 orang perempuan. Anak panti tersebut mengikuti kegiatan pendidikan pada tiga lembaga pendidikan dalam pesatren, taerdiri atas 8 orang anak panti belajar di Madrasah Ibtidaiyah, 64 orang anak panti belajar di Madrasah Tsanawiyah, dan 31 orang anak panti belajar di SMK Life Skill.

Sebagian besar santri pesantren ini mukim di asrama yang disediakan oleh pesantren, sedangkan sebagian kecil tidak mukim, yaitu pulang ke rumah orang tuanya setelah kegiatan belajar di pendidikan formal selesai.

Sedangkan tenaga pengajar dan pengasuh santri sebanyak 54 orang, terdiri atas 13 orang lakilaki dan 41 orang perempuan dengan latar belakang pendidikan SMA/Diploma 3 orang, S1 46 orang, dan S2 5 orang. Diantara guru-guru tersebut, terdapat 21 orang guru bersertifikasi, baik guru tetap maupun, maupun guru tidak tetap yang bertujuan untuk memenuhi jumlah jam mengajar 24 jam.

\section{Sarana dan Prasarana}

Untuk menunjang kelancaran kegiatan belajar mengajar dan kegiatan-kegiatan lainnya, Pondok Pesantren Attarbiyatussakilah menyediakan berbagai fasilitas, baik untuk santri putra maupun untuk santri putri, yaitu 1 unit rumah pimpinan pondok, 3 unit rumah pembina, 5 buah gedung ruang belajar, 3 gedung asrama, 1 ruang perpustakaan, 1 ruang laboratorium komputer, 1 unit gedung laboratorium IPA, 1 gedung keterampilan, 1 ruangan kantor/ tata usaha, 2 buah mesjid/mushalla, 3 buah lapangan olah raga, dan 2 buah dapur umum. Semua prasarana tersebut berdiri di atas tanah wakaf dengan luas 1 hektar.

\section{Sumber Dana dan Usaha Ekonomi}

Untuk pembiayaan pengadaan sarana dan prasarana, pelaksanaan kegiatan pendidikan, dan biaya hidup santri diperoleh dari berbagai sumber, di antaranya dana pribadi Ketua Yayasan melalui pinjaman kredit di beberapa bank di Kota Kendari, bantuan dari dermawan, bantuan dari pemerintah, dan usaha ekonomi produktif yang dilakukan oleh yayasan, yaitu peternakan sapi, kambing, dan ayam, budi daya ikan lele, pengoperasian hand traktor untuk persawahan, pengadaan rumah sewa, dan kegiatan perkebunan.

\section{KegiatanPemberdayaan Santri di Pondok Pesantren Attarbiyatussakilah}

Dalam rangka pemberdayaan santri, Pondok Pesantren Attarbiyatussakilah telah melakukan berbagai kegiatan keterampilan, baik atas prakarsa Ketua Yayasan, dan pembina, maupun prakarsa dari lembaga dan instansi dari luar yang memberi bantuan. Bentuk keterampilan yang dilakukan pesantren adalah sebagai berikut:

\section{Keterampilan Menjahit}

Keterampilan menjahit dilaksanakan pada tahun 2009 atas inisiatif M. Harfin H. A. Rahman, seorang pensiunan guru (PNS) dan berprofesi sebagai penjahit. Selain bertujuan memberikan bekal keterampilan menjahit kepada santri, juga membantu biaya santri, sehingga santri tidak lagi membebani orang tua untuk membeli baju, karena sudah dapat menjahit bajunya sendiri.

Santri yang dibina dalam keterampilan menjahit ini adalah santri yang berminat dalam keterampilan menjahit ini sebanyak 15 orang. Kegiatan keterampilan menjahit ini dilakukan minimal empat kali seminggu, setelah pelaksanaan Shalat Ashar di gedung vokasional (keterampilan) pesantren yang juga berfungsi sebagai kantor pesantren dengan menggunakan 10 mesin jahit, terdiri atas enam buah mesin jahit biasa, satu mesin obras, dan 3 mesin jahit khusus untuk kain kos.

Tahapan-tahapan dalam materi keterampilan menjahit yang diajarkan kepada santri adalahcara mengukur orang, peletakan ukuran di atas kertas, menggambar pola, menggunting pola, menerapkan pola pada kain, menggunting kain berdasarkan pola, latihan mengayun mesin jahit, dan menjahit kain yang sudah digunting dengan mesin jahit.

Agar kegiatan keterampilan ini berjalan secara berkesinambungan dengan keterbatasan bahan dan anggaran, kain yang telah dijahit dibuka untuk dijahit kembali, sampai kegiatan menjahit kain lancar. 
Pada awal tahun 2013, Pesantren Attarbiyatussakilah menjadi pelaksana sekaligus sebagai instruktur dalam kegiatan pemagangan santri pesantren se Sulawesi Tenggara selama 10 hari dengan melibatkan lima pesantren sebagai peserta atas biaya Kementerian Agama, dan salah satu materi keterampilan yang diajarkan dalam pemegangan ini adalah keterampilan menjahit. Materi keterampilan menjahit yang diajarkan dalam kegiatan pemagangan santri adalah: Teori dan praktek pembuatan pola baju santri dan sekolah, praktek menggunting baju santri dan sekolah, praktek menjahit baju santri dan sekolah, teori dan praktek pembuatan pola celana panjang, membuat celana panjang, dan menjahit baju olah raga.

\section{Peternakan Sapi}

Kegiatan peternakan sapi di pesantren ini dimulai pada tahun 2006atas bantuan Kementerian Pertanian sebanyak 20 ekor sapi dengan anggaran Rp.175 juta. Seluruh sapi bantuan ini diserahkan kepada orang tua/walisantri untuk dipelihara dengan sistem bagi hasil. Akan tetapi kegiatan peternakan sapi ini tidak berjalan dengan baik, karena sebagian peternak sapi itu menjual sapi peliharaannya tanpa penyampaian kepada pimpinan pesantren. Dengan kasus tersebut, semua sapi yang telah diserahkan kepada orang tua/wali santri diberikan secara gratis oleh pimpinan pesantren untuk memenuhi kebutuhan hidupnya.

Pada tahun 2008, kegiatan peternakan sapi dilanjutkan lagi dengan adanya bantuan dana Lembaga Mandiri yang Mengakar di Masyarakat (LM3) dari Kementerian Pertanian sebanyak Rp. 250 juta yang diwujudkan dalam bentuk peternakan 40 ekor sapi untuk pengembangan sapi betina produktif dan penggemukan sapi potong. LM3 merupakan lembaga mandiri yang dibentuk oleh Kementerian Pertanian yang yang tumbuh dan berkembang di masyarakat yang bertujuan untuk pemberdayaan dan pengembangan usaha agribisnis, sekaligus upaya untuk meningkatkan kesejahteraan masyarakat sekitarnya yang berupa gerakan moral melalui kegiatan pendidikan dan keterampilan dalam rangka meningkatkan kesejahteraan masyarakat.

Pada mulanya, pemeliharaan sapi ini dikelola oleh pimpinan dan pembina bersama santri pesantren, kemudian pemeliharaannya diserahkan kepada beberapa orang yang dianggap mampu dan dipercaya pada daerah transmigrasi di Kabuapten Konawe dengan sistem bagi hasil.Hal itu dilakukan karena keterbatasan makanan yang tersedia dan keterbatasan waktu bagi santri dalam pengelolaannya. Kegiatan ini masih tetap berjalan sampai sekarang dan jumlahnya sekitar 40 ekor dan merupakan salah satu usaha produktif sebagai sumber pendapatan pesantren.

\section{Peternakan kambing}

Peternakan kambing dilakukan di pesantren ini atas bantuan Lembaga Ilmu Pengetahuan Indonesia (LIPI) berupa kambing Etawa dengan anggaran Rp.25 juta dalam rangka pengembangan kambina betina produktif dan penggemukan kambing potong. Untuk membantu pengolahan makanan kambing, LIPI juga memberi bantuan mesin parut kelapa yang digunakan untuk mengolah kulit buah cokelat menjadi bahan makanan ternak.

Seperti halnya peternakan sapi, peternakan kambing pada awalnya dikelola oleh pimpinan dan pembina beserta santri pesantren dengan membuat kandang khusus yang dilengkapi dengan sistem pembuangan kotoran seperti kloset WC, sehingga tidak menimbulkan bau yang busuk. Oleh karena keterbatasan bahan makanan dan memerlukan waktu yang banyak dalam pengelolaannya, maka seluruh kambing diserahkan pengelolaannya kepada beberapa orang di Kabupaten Konawe dengan sistem bagi hasil. Peternakan kambing ini masih berjalan sampai sekarang dan jumlahnya sekitar 60 ekor, dan merupakan salah satu usaha produktif sebagai sumber pendapatan pesantren.

\section{Peternakan ayam potong}

Peternakan ayam potong dilakukan di pesantren dengan melibatkan santri pesantren atas bantuan dan pembinaan yang dilakukan oleh Balai Latihan Kerja (BLK) Kementerian Tenaga Kerja pada tahun 2009. Jumlah ayam potong yang dikelola sebanyak 100 ekor. Produk ayam potong ini dikonsumsi oleh santri pesantren (Dahniar, Wawancara, 18 September 2014).

\section{Peternakan Unggas}

Peternakan unggas dilakukan di pesantren sejak adanya santri yang tinggal di asrama pesantren, namun jumlahnya sangat terbatas. Peternakan 
unggas berkembang dengan adanya bantuan Pemda Provinsi Sulawesi Tenggara pada tahun 2011 dengan anggaran Rp. 13 juta. Jenis unggas yang diternakkan adalah ayam kampung, angsa putih, dan bebek manila. Hasil peternakan unggas ini dikonsumsi oleh santri, terutama pada saat bulan purnama ketika harga ikan sangat mahal. Kegiatan peternakan unggas ini masih berjalan sampai sekarang, karena merupakan bahan konsumsi santri pesantren.

\section{Budidaya Ikan Air Tawar}

Budidaya ikan tawar dilaksanakan di pesantren dengan menggunakan lima buah kolam yang dibuat oleh pimpinan pesantren dan pembina bersama dengan santri. Kelima kolam itu terletak di sekitar sungai kecil dan merupakan dataran rendah dalam lokasi pesantren, dan sekaligus dijadikan sebagai taman.

Jenis ikan tawar yang dibudidayakan adalah ikan lele jumbo dan ikan nila. Bibit ikan tawar tersebut dibeli di Balai Benih Ikan Air Tawar milik pemerintah Kabupaten Konawe dan Kota Kendari. Jumlah bibit yang dibeli sekitar 1000 ekor yang telah berumur sekitar satu minggu. Makanan ikan tawar itu adalah usus ayam dan ikan yang diolah dan nasi basi di pesantren, atau kotoran dan usus ikan yang dibeli di pasar. Lama budidaya ikan tawar tersebut sampai dapat dikonsumsi hasilnya sekitar enam bulan. Budidaya ikan lele jumbo dan ikan nila merupakan bantuan Dinas Pertanian Kota Kendari tahun 2011 dengan anggaran Rp. 25 juta pada tahun 2011.

\section{Keterampilan pembuatan batako, paving blok, dan cincin sumur}

Keterampilan pembuatan batako, paving blok, dan cincin sumurdilaksanakan di pesantren atas bantuan Kementerian Agama Pusat tahun 2011 dengan anggaran Rp.100 juta. Keterampilan pembuatan batako, paving blok, dan cincin sumur ini melibatkan pembina dan santri pesantren yang dibimbing oleh Kade, seorang instruktur yang sudah berpengalaman dalam pembuatan batako, pavingblok, dan cincin sumur. Agar keterampilan ini berjalan dengan baik, pesantren menyediakan rumah untuk instruktur yang ditugaskan melaksanakan bimbingan.

Bahan yang digunakan dalam pembuatan batako, pavingbalok, dan cincin sumur adalah semen dan pasir, sedangkan peralatan yang dibutuhkan adalah alat cetak, sekop, dan ember. Pada umumnya hasil produksi dari keterampilan ini digunakan untuk membangun sarana yang dibutuhkan oleh pesantren. Selain itu sebagian kecil dibeli oleh masyarakat yang membutuhkan.

Pada awal tahun 2013, Pesantren Attarbiyatussakilah menjadi pelaksana sekaligus sebagai instruktur dalam kegiatan pemagangan santri pesantren se Sulawesi Tenggara selama 10 hari dengan melibatkan lima pesantren sebagai peserta atas biaya Kementerian Agama, dan salah satu materi keterampilan yang diajarkan dalam pemegangan ini adalah keterampilan pembuatan batako, pavingbalok, dan cincin sumur. Materi yang diajarkan dalam keterampilan ini adalah: Teori dan praktek pembuatan batako, teori dan praktek pembuatan paving blok, dan teori dan praktek pembuatan cincin sumur.

\section{Keterampilan Sablon}

Keterampilan sablon dilaksanakan di pesantren ini apada awal tahun 2013 atas bantuan Kementerian Agama Pusat untuk kegiatan Pemagangan Santri yang dilaksanakan selama sepuluh hari dari tanggal 21- 30 Januari 2013. Biaya kegiatan ini adalah bantuan Kementaerian Agama dalam APBN-P Tahun 2012 sebanyak Rp. 33.000.000. Kegiatan ini dilaksanakan oleh Pondok Pesantren Attarbiyatussakilah dengan melibatkan 10 orang santri dari lima pondok pesantren, sehingga masing-masing pesantren diwakili oleh dua orang santri. Kelima pesantren yang diikutkan dalam pemagangan ini ini adalah: Pesantren Subulussalam Raha Kabupaten Muna, Bahrul Ulum Kabupaten Buton Utara, Fastabiqul Khaerat Ladongi Kabupaten Kolaka, Darul Mukhlisin Kota Kendari, dan Pesantren Attarbiyatussakilah Kota Kendari.

Keterampilan yang diajarkan dalam kegiatan pemagangan ini terdiriatas empatjenisketerampilan, yaitu Keterampilan pembuatan batako, paving blok, dan cincin sumur, keterampilan jaringan komputer dan internet, keterampilan menjahit pakian sekolah dan olah raga, dan keterampilan sablon. Pelajaran yang diterima dalam pelatihan ini terdiri atas teori dan praktek. Keterampilan sablon ini bekerjasama dengan Usaha Sablon Prahiyangan Kota Kendari sebagai instruktur. Keterampilan sablon ini hanya melibatkan dua orang santri pesantren 
Attarbiyatussakilah yang menjadi peserta kegiatan pemagangan.

\section{Keterampilan Pertanian}

Keterampilan pertanian dilakukan di pesantren sejak adanya santri yang tinggal di asrama pesantren dalam bentuk penanaman palawija dan sayur-sayuran, seperti jagung, terong, kacang panjang, lombok, sawi, mentimun, dan bayam. Selain itu, dilakukan juga penanaman nilam sebagai bahan baku parfum. Untuk pengolahan lahan pertanian dilaksanakan oleh pembina dan santri dengan menggunakan traktor tangan milik pesantren.Penanaman palawija dan sayur-sayuran dimulai pada awal musim hujan. Hasil penanaman palawija dan sayur-sayuran dimanfaatkan sebagai konsumsi santri dalam pesantren.

\section{Keterampilan Perkebunan}

Kegiatan perkebunan dilaksanakan pada masa awal berdirinya pesantren ini pada tahun 2004 atas bantuan Kementerian Pertanian dalam Gerakan Reboisasi Hutan dan Lahan (Gerhan) dalam bentuk penanaman berbagai tanaman jangka panjang, seperti rambutan, durian moutong, sukun, jeruk, mangga, kayu bitti, dan kayu jati. Kegiatan ini dilaksanakan pada dua kelurahan, yaitu Kelurahan Anduonohu dan Kelurahan Matabubu seluas 50 hektar. Lokasi pesantren masuk dalam wilayah sasaran kegiatan.

Kegiatan penanaman pohon di lokasi pesantren dilakukan oleh 20 orang personil TNI, dan pimpinan pondok pesantren diangkat sebagai Ketua Kelompok Tani yang ikut mengelola kegiatan tersebut. Buah pohon dari hasil penenaman tersebut sudah dapat diperoleh hasilnya sejak tahun 2012, misalnya buah rambutan dan buah durian moutong. Buah yangdiperoleh masih terbatas untuk dikonsumsi dalam lingkungan pesantren dan diberikan kepada orang yang membutuhkan.

\section{Keterampilan Komputer}

Keterampilan komputer di pesantren mulai diajarkan pada tahun 2010, saat SMK Life Skill berdiri dengan jurusan komputer. Santri yang ikut dalam keterampilan ini hanya santri yang belajar di SMK.

Pada awal tahun 2013, Pesantren Attarbiyatussakilah menjadi pelaksana sekaligus sebagai instruktur dalam kegiatan pemagangan santri pesantren se Sulawesi Tenggara selama 10 hari dengan melibatkan lima pesantren sebagai peserta atas biaya Kementerian Agama, dan salah satu materi keterampilan yang diajarkan dalam pemegangan ini adalah keterampilan komputer. Materi yang diajarkan dalam keterampilan ini adalah: Teori dan praktek Teknik Komputer dan Jaringan (TKJ) serta teori dan praktek Jaringan dan Local Area Network (LAN).

\section{Keterampilan memasak}

Keterampilan memasak adalah keterampilan yang dilaksanakan oleh seluruh santri Pondok Pesantren Attarbiyatussakilah, karena pelayanan makan santri di dalam pondok diserahkan kepada santri. Santri diberi tugas setiap hari secara berkelompok untuk memasak nasi dan mencuci piring secara bergilir yang dikoordinir oleh isteri ketua yayasan atau pembina yang ditunjuk, sedangkan bahan makanan disiapkan oleh yayasan. Setiap kelompok terdiri dari tujuh orang santri, empat orang santri bertugas memasak nasi, dan tiga orang santri bertugas mencuci piring. Pengolahan untuk lauk pauk dan sayur dilaksanakan oleh pembina dan santri puteri yang bertugas.

Waktu makan santri diatur oleh pesantren sebanyak tiga kali sehari, yaitu sarapan pagi pada jam 06.45-07.15, makan siang pada jam 13.30-14.00, dan makan malam pada 20.00-22.00. Kegiatan makan dilaksanakan pada ruangan makan di dapur umum masing-masing santri putera dan puteri.

\section{Peluang dan Tantangan Pemberdayaan Santri}

Kegiatan keterampilan dapat dilaksanakan di Pondok Pesantren Attarbiyatussakilah disebabkan oleh beberapa faktor, yaitu:

\section{Program kegiatan yayasan}

Salah satu kegiatan yang menjadi program Yayasan Pendidikan Bina Muallaf-Kaum Dhuafa adalah pembinaan keterampilan, sebagaimana yang dinyatakan dalam Anggaran Dasar Yayasan. Oleh karena itu, Yayasan berusaha menyediakan sarana dan prasarana yang menunjang kegiatan keterampilan dalam rangka memberikan bekal kepada santri pesantren yang pada umumnya adalah santri yang orang tuanya tidak mampu. 


\section{Minat santri}

Minat santri untuk mengikuti kegiatan keterampilan yang cukup beragam di pesantren cukup tinggi. Hal itu disebabkan karena selain sebagai modal dalam pembinaan keterampilan untuk masa depan santri, juga memenuhi kebutuhan mereka dalam pesantren yang diberikan oleh pesantren secara gratis.

\section{Tersedia sarana dan prasarana}

Lokasi pesantren yang cukup luas dan cocok untuk kegiatan beberapa keterampilan, seperti tanah yang subur untuk keterampilan pertanian dan perkebunan, serta kondisi lahan yang baik untuk budidaya ikan tawar.

\section{Bantuan berbagai lembaga dan instansi}

Sejak berdirinya sampai sekarang, pesantren ini cukup banyak memperoleh bantuan dari berbagai lembaga dan instansi dalam pembinaan dan pengembangan keterampilan, misalnya bantuan dari Kementerian Pertanian, Kementerian Koperasi, Kementerian Tanaga Kerja, Kementerian Agama, Kementerian Sosial, Pemerintah Provinsi Sulawesi Tenggara, dan bantuan Pemerintah Kota Kendari.

\section{Sekolah kejuruan berbasis pesantren.}

Yayasan mendirikan SMK Life Skill sebagai pendidikan kejuruan yang berbasis pesantren pada tahun 2010.

Beberapa faktor yang menjadi hambatan dalam kegiatan keterampilan adalah:

\section{Keterbatasan anggaran}

Beberapa keterampilan tidak dapat dilaksankan secara berkesinambungan, karena bahan baku yang digunakan membutuhkan dana yang cukup banyak, misalnya keterampilan menjahit, pembuatan batako, pavingblok, dan cincin sumur.

\section{Keterbatasan waktu}

Waktu santri untuk melaksanakan kegiatan keterampilan hanya dilaksankan pada waktu sore sekitar satu setengah jam, atau waktu libur sekolah, sehingga beberapa keterampilan tidak dapat dikelola oleh santri, seperti peternakan kambing dan sapi.

\section{Ketergantungan pada musim}

Kegiatan keterampilan yang memilki ketergantungan dengan musim tidak dapat dilaksanakan secara kontinu, misalnya keterampilan pertanian dan perkebunan tidak dapat dilakukan pada musim kemarau.

\section{Sarana transportasi}

Akses jalan dari jalan raya ke pesantren kurang lancar dan tidak bisa dilalui kendarann roda empat karena adanya jembatan kayu darurat yang hanya dapat dilalui oleh pejalan kaki, sepeda dan motor. Sehingga bahan yang berat sulit di datangkan, dan harus menggunakan kereta dorong dengan tenaga manusia. Hasil keterampilan pembuatan bataco, pavingblok, dan cincin sumur tidak dapat dipasarkan ke luar.

\section{PENUTUP}

Pondok Pesantren Attarbiyatussakilah yang berdiri sejak tahun 2004 di Kota Kendari telah memberikan peranan yang penting di berbagai aspek dalam kehidupan masyarakat, baik membangun tradisi keilmuan dan mengembangkan potensi berpikir, maupun merespons perkembangan zaman dengan penyelenggaraan berbagai keterampilan dalam pemberdayaan santri.

Pemberdayaan yang dilakukan pesantren tidak jauh berbeda dengan kegiatan pemberdayaan di berbagai pesantren di Indonesia, yaitu penjahitan, peternakan, pertanian, perkebunan, perikanan, komputer, pembuatan batako dan pavingblok. Program dan kegiatan pemberdayan yang ditetapkan oleh pesantren tidak terlepas dari upaya dan dukungan pimpinan pondok sekaligus sebagai ketua yayasan, kemandirian pesantren dan santri, serta sumber daya pembina.

Kegiatan keterampilan yang dilakukan pesantren memberikan manfaat yang besar kepada pesantren, santri, dan masyarakat. Manfaat pemberdayaan untuk pesantren adalah memberikan keuntungan untuk menutupi biaya kebutuhan sehari-hari di lingkungan pesantren dan menjadi modal produktif dalam pengembangan kegiatan pesantren. Manfaat untuk santri adalah memberikan dasar keterampilan sebagai bekal untuk hidup di tengah-tengah masyarakat. Manfaat untuk masyarakat adalah menggerakkan potensi ekonomi dan menciptakan lapangan pekerjaan dalam kehidupan masyarakat.

Pemberdayaan santri melalui berbagai keterampilan dapat berjalan karena didukung oleh 
faktor geografis lokasi pesantren, topografi lahan, partisipasi masyarakat, dan kebijakan pemerintah. Sementara tantangan yang dihadapi adalah keterbatasan anggaran dan waktu, ketergantungan pada musin, dan tidak lancarnya akses transportasi.

Hasil yang dicapai dalam strategi pemberdayaan ini adalah adanya peningkatan potensi yang dimiliki oleh para santri sesuai dengan kemauan dan minat mereka. Tidak hanya kualitas pendidikan keagamaan dan pendidikan umum lainnya yang mengalami peningkatan, akan tetapi dengan bekal pemberdayaan maka mereka memiliki ketrampilan dan kemampuan untuk bertahan hidup jika keluar dari Pondok Pesantren nantinya. Para santri menjadi lebih mandiri, bertanggung jawab, dan ikut berperan / berpartisipasi secara aktif dalam setiap kegiatan.

\section{UCAPAN TERIMA KASIH}

Peneliti mengucapkan banyak terima kasih kepada berbagai pihak, sehingga tulisan ini ada di tangan pembaca, di antaranya Kepala Balai Penelitian dan Pengembangan Agama Makassar, pejabat Kementerian Agama di Kota kendari, para informan penelitian, dan Tim Redaksi Alqalam.

\section{DAFTAR PUSTAKA}

Alhadza, Abdullah (a), dkk. 2009. Sejarah Penyebaran Islam di Sulawesi Tenggara. Kendari: Universitas Muhammadiyah.

Alhadza, Abdullah, (b) dkk. 2009. Sejarah Perkembangan Pendidikan Islam di Sulawesi Tenggara. Kendari: Unit Wira Usaha Universitas Muhammadiyah.

Arifin. 1995. Kapita Selekta Pendidikan Islam dan Umum. Jakarta: Bina Aksara.

Azra, Azyumardi. 2005. Jaringan Ulama Timur Tengah dan Kepulauan Nusantara Abad XVII \& XVIII: Akar Pembaruan Islam Indonesia. Jakarta: Prenada Media.

Melamba, Basrin. dkk. 2013. Tolaki: Sejarah, Identitas, dan Kebudayaan. Yogyakarta: Lukita.

Badan Pusat Statistik Kota Kendari, 2014. Kota Kendari dalam Angka 2013. Kendari: Biro Pusat Statistik Kota Kendari.

Badan Pusat Statistik Sulawesi Tenggara. 2014. Sulawesi Tenggara dalam Angka 2013.
Kendari: Biro Pusat Statistik Sulawesi Tenggara.

Daulay, Haidar Putra. 2007. Sejarah Pertumbuhan dan Pembaruan Pendidikan Islam di Indonesia. Jakarta: Kencana Prenada Media Group.

Faozan, Achmad. 2006. "Pondok Pesantren dan Pemberdayaan Ekonomi”, dalam Ibda': Jurnal Studi Islam dan Budaya, Vol 4, No. 1.

Ghazali, M. Bahri. 2001.Pendidikan Pesantren Berwawasan Lingkungan: Kasus Pondok Pesantren AnNuqayah Guluk-Guluk Sumenep, Madura. Jakarta: Pedoman Ilmu.

Hafid, Anwar dan Misran Safar. 2007. Sejarah Kota Kendari. Bandung: Humaniora.

Kanwil Kemenag Provinsi Sulawesi Tenggara. 2012 Profil Madrasah Aliyah Sulawesi Tenggara Tahun 2012. Kendari: Bidang Madrasah dan Pendidikan Agama Islam Kanwil Kementerian Agama Provinsi Sulawesi Tenggara.

Madjid, Nurcholis. 1998. Bilik-Bilik Pesantren: Sebuah Potret Perjalanan. Jakarta: Paramadina.

Mastuhu. 1994. Dinamika Sistem Pendidikan Pesantren: Suatu Kajian tentang Unsur dan Nilai Sistem Pendidikan Pesantren. Jakarta: INIS

Melamba, Basrin dkk. 2011. Kota Lama, Kota Baru Kendari. Yogyakarta: Teras.

Milles dan Huberman. 1992. Analisa Data Kualitatif. Jakarta: UI Press

Murtadho, M. Pesantren dan Pemberdayaan Ekonomi (Studi Kasus Pesantren Baitul Hamdi dan Pesantren Turus di Pandeglang). http:// balitbangdiklat.kemenag.go.id/. Diakses 20 Juni 2014

Rahardjo, Dawam. 1985. Pergulatan Dunia Pesantren Membangun dari Bawah. Jakarta: P3M.

Suhartini, A. Halim, dkk. 2005. Manajemen Pesantren, Yogyakarta; Pustaka Pesantren.

Suharto, Edi. 2005. Membangun Masyarakat, Memberdayakan Rakyat. Bandung: Refika Aditama.

Supriyanto, dkk. 2009. Sejarah Kebudayaan Islam Sulawesi Tenggara. Kendari: Kerjasama Kanwil Kemenag dengan Universitas Muhammadiyah.

Supriyanto, dkk. 2011. Sejarah Pondok Pesantren di Sulawesi Tenggara. Kendari: Kerjasama 
Lembaga Pengkajian Islam Sulawesi Tenggara dengan Kanwil Kemenag Provinsi Sulawesi Tenggara.
Turmudi, Endang. 2004. Perselingkuhan Kiai dan Kekuasaan. Yogyakarta: LKiS. 